\title{
Utjecaj medija i uloga odraslih na odgoj i obrazovanje djece predškolske i rane školske dobi
}

Stručni rad__ DOI 10.22522/cmr20190151__ primljeno 24. siječnja 2018

UDK: $316.774-042.3: 373.2-053.2$

$316.774-0.42 .3: 37-053.2$

\section{Antonija Đuran}

DV Medo Brundo, Zagreb, Hrvatska.

E-adresa: tonkaduran@yahoo.com

\section{Diana Koprivnjak}

DV Medo Brundo, Zagreb, Hrvatska.

E-adresa: dianakoprivnjak@gmail.com

\section{Nataša Maček}

DV Medo Brundo, Zagreb, Hrvatska.

E-adresa: natasha_zg_rtc@hotmail.com

\section{Sažetak}

Djeca su od najranije dobi izložena medijima. Samim time oni imaju veliki utjecaj na djetetov odgoj i obrazovanje. Zbog količine različitih medija njihov utjecaj je brz i neprimjetan, ali istovremeno snažan. Rad se bavi prikazom pozitivnog i negativnog utjecaja medija u obrazovanju djece. Posebno su naglašene pozitivne strane kao što je dostupnost različitih informacija koje djeci služe kako bi se afirmirali kao članovi društvene zajednice kojoj pripadaju. Cilj medijskog obrazovanja je pomoći djeci da razviju kritički stav prema medijima kako bi mogli na kvalitetan način koristiti medije u odgoju i obrazovanju. Odrasli imaju veliku važnost pri odabiru medijskih sadržaja te bi trebali naučiti djecu kvalitetnom korištenju medija u svrhu učenja i vlastitog napretka. Važnost odraslih osoba bitna je jer nerijetko dolazi do negativnih posljedica utjecaja medija zbog velike količine izloženosti informacijama koje je djeci teško selektirati. Neselektiranje sadržaja može ostaviti dugoročne posljedice na razvoj djeteta, kako u školskom tako i u društvenom životu.

Ključne riječi: mediji, djeca, odgoj, obrazovanje 


\section{Uvod}

Današnje vrijeme odlikuju mnogobrojne promjene u društvu i načinu njegova funkcioniranja. Jedna od najznačajnijih i najbržih promjena dogodila se u ulozi medija u životu čovjeka, kako odraslih tako i djece, te utjecaju medija na njihov život. U današnje vrijeme funkcioniranje svijeta nezamislivo je bez masovnih medija. Prema Zrinjki Peruško-Čulek (2011) svaki masovni ili komunikacijski medij nastaje primjenom nove i poboljšane tehnološke ideje te se razvija u novu, kako kulturnu tako i društvenu formu, odgovarajući na potrebe pojedinca. Širenjem i upotrebom, $\mathrm{u}$ interakciji s društvenom sredinom, mijenja oblike društvene interakcije $\mathrm{i}$ komunikacije. Usporedno s pojavom masovnih medija, kao i njegovim širenjem, postavljaju se različita pitanja i rasprave o njihovim funkcijama i potencijalnom utjecaju.

Mediji su sredstva komunikacije koja se prilagođavaju društvenim promjenama. Mediji, kao što su knjiga, radijske i televizijske postaje, novine i časopisi, prožimaju sva područja ljudskog života, no mobiteli, internet i novi mediji na poseban i osobit način dio su života djece i mladih (Labaš, 2011). Prema Valentini Mandarić (2012, str. 132), suvremeni mediji oblikuju čovjekovu svakodnevicu na svim razinama života: utječu na radne navike, kreativnost, socijalizaciju i komunikaciju. Bez medija modernom čovjeku teže bi bilo uspješno komunicirati, planirati, zabavljati se, kao i provoditi slobodno vrijeme (Mandarić, 2012).

Mediji imaju ambivalentnu ulogu u suvremenoj odgojnoj paradigmi jer su s jedne strane obrazovno-informativnog karaktera, dok s druge strane poprimaju oblik manipuliranja i/ ili indoktrinacije, posebice kod djece i mladih (Miliša, Zloković, 2008, str. 131). Medijska pismenost označava sposobnost kritičke analize medijskih ponuda, istovremeno koristeći medije kao sredstvo za kreativno izražavanje. Ona vodi k realizaciji glavnog cilja medijskog odgoja i obrazovanja. Medijska se kompetencija odnosi na analizu medijskih sadržaja (Baacke, 2007, str. 67). Medijska pismenost je najniža razina svladavanja osnovnih vještina kod prepoznavanja vizualnih simbola i rada na računalima te drugim medijskim sredstvima (Tolić, 2009). Sveukupnost odnosa medijske pismenosti i medijskog obrazovanja nalazi se u pojmu medijske kompetencije. Suština medijskog odgoja je u svladavanju principa istraživanja kako živjeti s medijima (Tolić, 2009). Mediji su važni za organizaciju iskustava i uvjeta učenja. Konstruktivističke teorije učenja ističu aktivnost i suradnju učenika u okolini učenja gdje su digitalni mediji neodvojiv element. Kurikulumske su teorije usmjerene prema ishodima učenja, a mediji su u njima važni jer posreduju iskustva učenja kojima se postižu željeni ishodi (Tolić, 2009). 
U ranoj dječjoj dobi sve je veća upotreba medija pa je samim time i njihov utjecaj na djecu i mlade velik, a sami mediji postaju važan element obrazovanja (Matyjas, 2015). Sve veće otvaranje medija društvu, ali i obrnuto, dovelo je do prilika u kojima mediji igraju značajnu ulogu u našim životima. Pozitivni aspekti njihova djelovanja su brojni, no upravo zbog važnosti koju oni imaju u društvu i moći koju posjeduju, javljaju se i negativne posljedice tog djelovanja. Dostupnost medija, koji odavno žive u dubokom suživotu s gotovo svakim domom i svakom obitelji, dovelo je do toga da su njihovu utjecaju sve više izloženi i oni najosjetljiviji članovi društva koji se tek oblikuju kao osobe - djeca, adolescenti i mladi (Labaš, Maleš, 2017). Posebnu pozornost javnosti i stručnjaka izaziva propitivanje relacije masovnih medija i djece kao najugroženijeg segmenta populacije (Ilišin, Marinović Bobinac, Radin, 2001). Ono što valja naglasiti jest to da su svi okruženi i osuđeni na život s medijima. U skladu s tim valjalo bi dobro upoznati na koji način oni djeluju na pojedinca i društvo. Pojedinac može umjesto pasivnog primanja poruka stvoriti odnos međusobnog, uzajamnog djelovanja. Kako bi se to ostvarilo, važnu ulogu ima medijska pismenost. Medijska se pismenost definira kao mogućnost pristupa, analize, ocjene i proizvodnje novinarskih priloga u najrazličitijim oblicima, a kada su djeca u pitanju, osobito je značajna refleksivna razina koja omogućuje razmišljanje o medijskim sadržajima i oblicima. Ona uči kritičnosti prema ponuđenim proizvodima, prema kanalima koji ove proizvode omogućuju i prema vlasnicima koji ih određuju (Košir, Zgraljić, Ranfl, 1999, str. 29). Košir i sur. (1999) naglašavaju važnost medijske pismenosti kao takve budući da nam pomaže da razumijemo kako i na koji način su mediji zaslužni za oblikovanje naše predodžbe o svijetu i o nama samima. Ističu da se medijska pismenost može postići isključivo i samo sustavnim odgojem za medije.

Zlatko Miliša (2008) naglašava da se kulturni izričaji suvremenih društava mijenjaju osobito pod naletom medijskog oblikovanja svijeta. Mediji imaju veliki utjecaj na socijalizaciju mladog naraštaja. Mladima je, $s$ jedne strane, problem to što se moraju orijentirati na sve kompliciranije odnose s kojima moraju ovladati. S druge strane, otvaraju se sve bogatije mogućnosti informiranja, komuniciranja i mobilnosti, nego starijim generacijama.

\section{Utjecaj medija}

Život u suvremenom društvu brzih promjena zahtijeva nova znanja, vještine, sposobnosti, odnosno razvoj novih kompetencija pojedinca koji stavljaju naglasak na razvoj inovativnosti, rješavanje problema, razvoj kritičkog mišljenja i informatičke pismenosti (Nacionalni okvirni 
kurikulum, 2011). S obzirom na činjenicu da su djeca izložena utjecaju medija, a obrazovanje je vrijeme učenja i stjecanja vještina, važno je stvoriti kritički stav prema sadržaju medija koji nam se nudi i prikazuje. Podučavanje djece o medijima znači, između ostalog, učiti ih da kontroliraju korištenje medija i da shvate kako različiti mediji određuju njihovo vrijeme i utječu na njihova razmišljanja i osjećaje. Medijska pismenost pomoći će pojedincu da shvati medijske poruke umjesto da ih pasivno prihvati. Čini se da mediji toliko utječu $u$ periodu djetinjstva i odrastanja na djecu i mlade da se često susrećemo s pojmom medijskog djetinjstva (TV djetinjstvo ili računalno djetinjstvo). Izdebska (2006, str. 169 prema Matyjas, 2015) ističe da medijsko djetinjstvo obuhvaća pet aspekata: 1 . dnevnu i višekratnu prisutnost medija u dječjim životima; 2 . količinu vremena posvećenu upotrebi medija, koliko često djeca koriste medije, interese i hobije povezane s medijima i vrste programa koje djeca gledaju; 3. način na koji djeca koriste i primaju medije; 4. određeni odnos djeteta i medija; 5. učinci odnosa između djece i medija, uključujući iskustvo, ponašanje i emocije koje proizlaze iz medija. Današnja djeca i mladi primaju većinu informacija putem masovnih medija. U vrtićima i školama primjena medija u odgoju i obrazovanju još uvijek nije dosegla razinu koja je potrebna kako bi djeca shvatila razliku između korištenja medija za učenje i za razonodu (Matyjas, 2015). Medijska pismenost će omogućiti mladima da postanu kritički mislioci i kreativni proizvođači sve većeg broja i spektra poruka. Društvo bi trebalo promovirati medijsku pismenost kao jedan od svojih osnovnih interesa, odnosno da djeci i mladima pomogne da razviju vještinu potrebnu za opstanak u svijetu eksplozivnog razvoja medija (Krilić, 2010). U skladu s time, Europska unija je odredila osam kompetencija potrebnih za cjeloživotno učenje među kojima su i digitalne kompetencije. Razvoj digitalnih kompetencija odnosi se na osposobljavanje za kritičku i sigurnu upotrebu informacijsko-komunikacijske tehnologije za rad, kako u osobnom tako i u društvenom životu, te komunikaciji. Njezini ključni elementi su osnovne informacijsko-komunikacijske vještine i sposobnosti poput upotrebe računala za pronalaženje, procjenu, pohranjivanje, stvaranje, prikazivanje i razmjenu informacija te razvijanje suradničkih mreža putem interneta (Nacionalni okvirni kurikulum, 2011). Postati medijski pismen ne znači zapamtiti činjenice ili statistiku o medijima, već naučiti postavljati prava pitanja o onome što gledamo, čitamo ili slušamo. Naučiti „čitati“ medije jedan je od važnijih ciljeva medijske pedagogije budući da mediji ne prezentiraju stvarnost, već ju reprezentiraju (Djecamedija.org, n.p.). U takvom medijskom okruženju, gdje se tradicionalni mediji isprepleću s novim tehnologijama, s pravom se može reći da masovni mediji postaju sastavni dio života (Samardžić, 2013). Košir i sur. (1999) navode da medijska pismenost obuhvaća više razina - refleksivnu i produktivnu. Refleksivna razina medijske pismenosti 
omogućuje razmišljanje o medijskim sadržajima i oblicima. Također, potiče razvoj kritičnog promišljanja prema ponuđenim proizvodima, prema kanalima koji te proizvode omogućuju kao i prema vlasnicima koji ih određuju. Produktivna razina medijske pismenosti omogućuje pojedincu da sudjeluje u medijskoj proizvodnji. Cjelovit medijski odgoj i obrazovanje omogućuje djeci da se socijalno zbližavaju, učvršćuju komunikaciju te da pomoću masovnih medija komuniciraju s drugima. Stjecanje medijske pismenosti može biti uistinu uspješno samo ako uzmemo u obzir odnos između specifičnosti medija i načina na koji pojedinci shvaćaju te specifičnosti. Nadalje, Ivanović (2014) naglašava da ovakva zamišljena medijska pismenost može pridonijeti stjecanju mnogih društvenih vrijednosti.

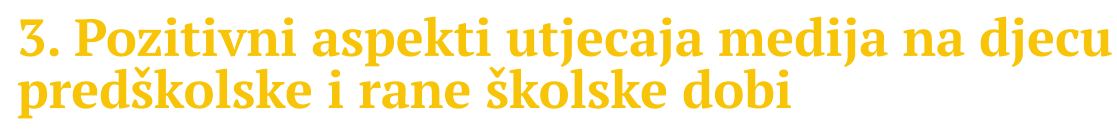

Prema istraživanju koje su proveli Poliklinika za zaštitu djece i mladih Grada Zagreba i Hrabri telefon (2013) djeca predškolske dobi provode 2,4 sati radnim danom, a 3 sata vikendom pred ekranima koristeći različite medijske sadržaje. Upravo zbog sveprisutnosti medija i njihove neophodnosti u svakodnevnom životu, dovode se u pitanje strukture odnosa koje nastaju s medijima i utjecaj medija na život suvremenog čovjeka, konkretnije djeteta. Integriranjem različitih medija, djeca kreiraju i proširuju svoje kognitivne, psihičke, kreativne i socijalne kvalitete. Oni postaju aktivni sudionici procesa učenja jer između medija i djeteta postoji dijalog. Mediji zahtijevaju aktivnost djeteta $u$ potrazi za informacijama, ono prelazi $s$ predmeta na drugi povezani predmet. Interaktivnost djetetu omogućuje biranje, ali i povratno djelovanje na medij u stvarnom vremenu, zahvaljujući postojanju više navigacijskih putanja. Drugim riječima, ako ishod igrice, na primjer, nije zadovoljio očekivanja djeteta ono ju može ponovno odigrati dok učinak ne bude zadovoljavajući (Kovač, 2011).

Suvremeni masovni mediji imaju veliki potencijal u procesu globalizacije. Različite vrste medija imaju korisne primjene $u$ našem svakodnevnom životu. Oni stvaraju povoljne uvjete za razvoj djece te omogućuju djeci da razumiju globalna pitanja poput ratova, nuklearnih prijetnji, bolesti, gladi, beskućništva, siromaštva i slično. Štoviše, mediji promoviraju kulturnu različitost i podučavaju toleranciju. Oni stvaraju nove mogućnosti za bolje obrazovanje, odnosno $u$ obrazovanju nalaze različite primjene: od nastavnih programa za učenje $i$ vježbe, od baza podataka i alata preko igara za učenje, pokusa i simulacija do kompleksnih komunikacijskih i kooperacijskih okruženja (Nadrljanski, Nadrljanski, Bilić, 2007, str. 530). 
Osim toga, prema Hoffmanu (2014), masovni mediji omogućuju djeci sudjelovanje na kulturnim događanjima, kako nacionalnim tako i međunarodnim. Može se reći da su danas mediji, zajedno sa školom i obitelji, postali jedno od važnih obrazovnih okruženja. Mediji kao suvremena sredstva za podučavanje nude brojne obrazovne mogućnosti te se mogu uspješno koristiti u različitim fazama učenja, uključujući time i razinu integriranog obrazovanja ranog djetinjstva. Zanimljivi grafičko-zvučni efekti, često i sami likovi koji dolaze iz knjiga, filmova i već su poznati djetetu, uzrokuju da rad s računalom postaje učenje kroz igru. Zbog tehničkih mogućnosti računala, djeca i učenici nisu samo pasivni promatrači, nego su i suučesnici učenja te jedna od važnih uloga jest da korištenje suvremenih medija omogućuje razvoj okulomotorne koordinacije (Anetta, 2008). Nadalje, mediji podupiru razvoj kreativnog razmišljanja, mašte te potiču razvoj vlastite inicijative djeteta (Anetta, 2008). Zahvaljujući medijima moguće je brzo provjeriti znanje stečeno od strane učenika i to na ugodniji način od tradicionalnog ispitivanja, a to je igrom. Istraživanja o korištenju suvremenih medija u procesu obrazovanja pokazuju da informatička tehnologija potiče mentalni proces djeteta, ima pozitivan učinak na hipotetsko razmišljanje i logičku analizu, a računalne igre potiču razvoj okulomotorne koordinacije (Subrahmanyam i sur., 2000). Računalne igre imaju prednost zato što se temelje na narativnoj strukturi koju je lakše zapamtiti nego što je to s knjigama (Subrahmanyam i sur., 2000). Važno je da oni omogućuju neposrednu nagradu u obliku procjene izvedbe igrača. Ova je činjenica osobito važna za djecu koja, ako dobiju brzu, pozitivnu reakciju, žele ponoviti situaciju, podupirući proces njihova učenja. Računala se koriste $u$ različitim područjima obrazovanja. Kovač (2011) ističe da su iznimno zanimljive multimedijske bajke koje utječu na razvoj mašte kod djece, na poboljšanje vještina čitanja s razumijevanjem te obogaćuju rječnik. Računalo se koristi i za podučavanje stranog jezika i povijesti. Multimedijalno računalo može razviti maštu, glazbenu memoriju i osjećaj za ritam te ono omogućuje učenicima da se upoznaju sa zvukom različitih instrumenata i stvaraju vlastite melodije (Tabol, 2002). Računalno obrazovanje pomaže poboljšati matematičku tehniku u okviru zbrajanja, oduzimanja, množenja i dijeljenja. Naravno, starija djeca i mladi ljudi imaju priliku računalo koristiti tijekom nastave fizike, kemije, geografije i biologije. Učenje kod kuće uz korištenje računala je također privlačnije za djecu, a ono što slijedi može povećati obrazovne ishode. Kroz interaktivne razrede moguće je razviti sveobuhvatne vještine: kreativnost, koncentraciju i kognitivne sposobnosti. Kao što je istaknuto, uloga računala nije ograničena na korištenje u obrazovanju, već se također koristi u različitim područjima odgoja. Kazubowska (prema Hoffmann, 2014, str. 17) navodi da rad s računalom razvija upornost, zahtijeva samoodređenje te u slučaju grupnih aktivnosti, uči suradnju s vršnjacima i timskim odgovornostima. Odgovarajući računalni softveri također omogućuju njihovu uporabu za dijagnostičke, preventivne $\mathrm{i}$ 
terapijske ciljeve. Hoffmann (2014) dalje navodi da široke i raznovrsne grafičke sposobnosti mogu značajno poboljšati stimulaciju razvoja psihomotornog sustava djece i sposobnost individualizacije neke vrste pomoći za dijete te da korištenje masovnih medija jasno aktivira i ohrabruje dijete, što u kombinaciji s pravilno usklađenim vježbama, u smislu njihove brzine i stupnja težine, omogućuje svakom djetetu uspjeh (Kazubowska prema Hoffmann, 2014). Pomoću računala, odnosno interneta, moguće je i puno lakše učenje na daljinu koje može biti posebno korisno za djecu sa zdravstvenim problemima. Uzimajući u obzir brojne prednosti korištenja elektroničkih medija na razini integriranog obrazovanja u ranom djetinjstvu, ne postoje značajne prepreke razvoju kompetencija u informacijskoj tehnologiji koja započinje u prvim godinama dječjeg obrazovanja. U ranoj školskoj dobi postoji velika potreba za zabavom u kombinaciji s kreativnom aktivnošću koja je važna komponenta dječjeg mentalnog razvoja. Korištenje elektroničkih medija stoga je nužan element svake suvremene škole (Hoffmann, 2014). Osim na učenje, razvoj tehnologije i novih medija utjecao je i na promjene u kontekstu razvoja dječje igre. Razvojem tehnologije dječja igra evoluirala je $u$ jednom drugom smjeru, smjeru koji još uvijek nije dovoljno istražen, koji je često negativno osuđivan i optuživan za sve negativne promjene $u$ dječjem životu. Osnovna razvojna karakteristika djece je otvorenost za novo i drugačije. Djeca su po svojoj prirodi istraživači koji istražuju sve u svom okruženju. Mogućnosti tehnologije i novih medija u dječjoj igri samo su još jedan novi segment koji je potrebno istražiti i koji postaje zanimljiv predmet dječjeg istraživanja. Jednostavnost i otvorenost prema novinama je nešto što je kod djece potrebno cijeniti i njegovati. Na tragu tih promjena pred odrasle se postavljaju novi zadaci kao što su potpuna otvorenost za nove strategije i načine učenja, odbacivanje svih predrasuda, ograničenja i neznanja (Rogulj, 2014). Kada je sve to iza nas, možemo zajedno s djecom krenuti u veliko istraživanje novih medija kao novog i neizbježnog dijela nove dječje igre i obrazovanja. Prihvaćanje snažnog utjecaja novih medija na dječju igru omogućuje nam određenu dozu kontrole nad kvalitetom igre s ciljem zaštite djece. Tehnologija i novi mediji postali su dio dječje igre (Rogulj, 2014).

\section{Negativni utjecaji medija na djecu predškolske
i rane školske dobi}

Mediji i medijski uređaji, osobito televizija, internet i mobitel, postali jedan od najvažnijih čimbenika u socijalizaciji (Suvajdžić, 2016). Utječu na društvena ponašanja, nezaobilazno su sredstvo u informiranju, oblikovanju i prenošenju vrednota, stvaranju vizije svijeta i života. Novi mediji nametnuli su se kao nova „društvena institucija“ u socijalizacijskom procesu 
(Burić, 2011). Bez sumnje, masovni mediji pružaju brojne obrazovne mogućnosti. No, s druge strane, oni mogu imati negativne implikacije za djecu jer virtualna stvarnost, koja se obično uvelike razlikuje od stvarnog svijeta, može stvoriti rizike osobito za psihološki i fizički razvoj. Djeca mogu biti izložena riziku od zloupotrebe ili ovisnosti o internetu (Forma, Matyjas, 2015). Podizanje svjesnog društva protiv negativnog utjecaja medija stavlja naglasak na medijsku pismenost koja postaje sve važnija kao dio obrazovanja. U tom kontekstu nastojimo podići pojedince koji su kompetentni za aktivno i sigurno korištenje medija (Sisman, UlugYurttas, 2015). Prema Adeli Bradea i Valentinu Cosmin Blandul (2015), neki od negativnih utjecaja koji mediji imaju su slabljenje sposobnosti slušanja i praćenja prezentiranog materijala, nesposobnost odvajanja realnog od virtualnog svijeta te smanjenje neposredne socijalne interakcije, jer svu potrebu za komunikacijom ispunjavaju putem različitih aplikacija i socijalnih mreža. Taj nedostatak komunikacije licem u lice uzrokuje općenito otuđenje, nakon čega može uslijediti gubitak komunikacijskih vještina u stvarnom životu koji dovodi do nesnalaženja $u$ društvu (Stančić i sur., 2007). Posljedično tome slijedi smanjenje samopouzdanja i pozitivne slike o sebi što može znatno utjecati na psihološko zdravlje djeteta. Aric Sigman (2010) ističe da dug boravak djece ispred ekrana dovodi djecu do smanjene fizičke aktivnosti pri čemu veliki broj djece konzumira obroke pred ekranima i na taj način ne osvještavaju količinu hrane koje pojedu što dovodi do drugog velikog zdravstvenog problema, a to je pretilost djece. Gledanje televizije potiče sjedilački način života i povećanje unosa energije. Tijekom boravka ispred ekrana često se poseže za visokokaloričnom hranom što uvelike podupire i sam propagandni program koji je fokusiran pretežito na hranu koja je bogata mastima i šećerima poput slatkiša, sokova i brze hrane (Sigman, 2010). Također Hrvoje Stančić i sur. (2007) navode kako su negativni utjecaji medija veća izloženost djece zlostavljanju od strane hakera (podaci i krađe autorskih prava, krađe računa, virusi) i seksualnim grabežljivcima kojima su djeca ciljana meta baš iz razloga što nisu dovoljno educirana i nemaju razvijene kritičke stavove o opasnostima elektroničkih medija. Nadalje, kao negativan faktor izdvaja se i nasilje preko interneta elektronično nasilje. Nasilje preko interneta je opći pojam za svaku komunikacijsku aktivnost cyber tehnologijom koja se može smatrati štetnom kako za pojedinca tako i za opće dobro (Poliklinika-djeca.hr, n.p.). Tim oblikom nasilja, koje je u znatnom porastu, obuhvaćene su situacije kada je dijete izloženo napadu od drugog djeteta ili grupe djece putem interneta ili mobilnog telefona. Ovakav način nasilja znatno može utjecati na dječje opće funkcioniranje i pojam o sebi te dovesti do depresije (Kowalski, 2008). Bez sumnje postoje mnoge mogućnosti i šanse, ali i prijetnje primjenom elektroničkih medija, a odrasli su ti koji će najviše doprinijeti pozitivnom, odnosno negativnom utjecaju medija (Matyjas, 2015). 


\section{Uloga odraslih u multimedijalom djetinjstvu}

Biti okružen medijima danas je stvarnost velike većine ljudi, a posebice je to stvarnost dječjih života. Prema Lani Ciboci, Igoru Kanižaju i Danijelu Labašu (2011) još se donedavno na medije gledalo kao na nešto tehničko što je zahtijevalo specifična znanja i sposobnosti, a danas je postalo općeprihvaćeno mjesto susreta i kontakata s prijateljima, mjesto gdje se kupuju ulaznice, knjige, razmjenjuju interesi i ideje. Božena Matyjas (2014) ističe kako je obitelj okruženje u kojem dijete prvi put upoznaje i koristi medije. Kućanstva modernih obitelji su opremljena raznim uređajima poput televizije, kamera, računala, multimedijalne opreme, internetskih konekcija, mobitela, ipad-ova i slično što upućuje na pozamašnu integriranost tehnologije u obitelji (Chou, Fen, 2014). Kako je već istaknuto u radu, djeca najveći dio svog slobodnog vremena provode uz jedan od oblika medija, a istodobno nemaju oblikovan kritički odnos prema medijskim sadržajima te su više izložena njihovim štetnim posljedicama (Sindik, 2012). Djecu mediji privlače te roditelji, odgojitelji i učitelji to moraju prihvatiti kako bi se nosili s novim izazovima djetinjstva. No, pitanje je jesu li se odrasli spremni nositi s tim izazovima. Prvo nacionalno komparativno istraživanje, provedeno prema metodologiji međunarodnog projekta EU Kids Online, predstavilo je prve rezultate istraživanja u studenom 2017. godine o medijskim navikama djece i njihovih roditelja. Temeljem ovog istraživanja moći će se razvijati nove obrazovne politike s ciljem osnaživanja djece i mladih u medijskoj pismenosti. Rezultati pokazuju kako je djeci i roditeljima potrebna edukacija. Potrebni su novi modeli medijskog odgoja ponajviše u skupini djece od 9 do 11 godina budući da je ovo vrlo osjetljivo razdoblje u kojem je djeci potrebna odlučnija pomoć roditelja i odgojno-obrazovnih institucija (Pravobranitelj za djecu, 2017).

Nadalje Ciboci, Kanižaj i Labaš (2011) ističu kako se roditelji i odgojitelji u dodiru s novim digitalnim medijima osjećaju razoružano. S jedne strane, svjesni su da su novi mediji zauzeli bitnu ulogu u djetinjstvu, no s druge strane se boje medija jer ih ne poznaju dovoljno dobro. Ne znaju točno što djeca rade $s$ tim medijima te se boje negativnog utjecaja medija na odrastanje djece. Stoga je medijsko opismenjavanje roditelja i odraslih od velike važnosti kako bi se smanjio osjećaj jaza između odraslih i djece, ali i kako bi roditelji mogli biti ti koji će djecu na pravilan način uvesti u svijet medija. No, prema Valentini Mandarić (2012), odgovorne osobe (roditelji, odgojitelji i učitelji) često zbog neznanja odgoj za medije svode na zaštitu od negativnih utjecaja, a manje pažnje posvećuju razvoju kritičkog promišljanja i odgovornom filtriranju medijskih mogućnosti i sadržajnih ponuda. Cilj odgoja za medije trebao bi biti osposobljavanje mladog čovjeka za samostalno korištenje medija te razvijanje 
kritičkog stava prema sadržajima koji mediji svakodnevno nude (Mandarić, 2012, str. 143). Da bi se navedeno moglo ostvariti aspekt medijskog opismenjavanja odraslih znatno dobiva na važnosti.

Budući da govorimo o djeci te o njihovim primarnim, odnosno sekundarnim odgojiteljima, moramo spomenuti i važnost igre. Igra je djetetova temeljna aktivnost, no igra djece također doživljava transformaciju. Današnje generacije djece digitalnog doba zahtijevaju od roditelja da uvrste digitalizaciju u svoju igru s djecom. Tu opet dolazimo do važnosti medijskog opismenjavanja odraslih koje će smanjiti strah od nepoznatog, izgraditi nove roditeljske kompetencije te omogućiti roditeljima približavanje suvremenom djetetu. Djeca čiji su roditelji bili uključeni u njihovu igru imaju kvalitetnije odnose sa svojim roditeljima te je dokazano da igra u kojoj su sudjelovali roditelji ima višestruke pozitivne utjecaje na sve aspekte djetetova života (Chou, Fen, 2014). Osnažuje njihove sposobnosti rješavanja i testiranja problema, obogaćuju njihova iskustvena istraživanja, komunikacijske vještine, osvještavaju važnost emocionalnih ekspresija, kontakta oči u oči, čekanja na red i slično. No, ono što je možda najvažnije, zajednička igra roditelja i djece osnažuje i produbljuje njihove odnose na emocionalnoj razini i doprinosi osjećaju prisnosti.

Utjecaj televizije i drugih medija, bio on pozitivan ili negativan, u roditeljskim je rukama (Ozdasli, Gol, 2013). Roditelji moraju preuzeti odgovornost za vrijeme koje djeca predškolske i rane školske dobi provode pred televizijom i drugim medijima. Vrlo je važno naći ravnotežu u načinu na koji su različiti mediji integrirani u dom (Chou, Fen, 2014). Nema sumnje da informacijske tehnologije utječu na obiteljske odnose, no način na koji su implementirane i sam roditeljski stil će usmjeriti hoće li taj utjecaj biti pozitivan ili negativan. Matyjas (2015) tvrdi da svaka obitelj može imati koristi od prikladne upotrebe masovnih medija. Kao što smo već naveli, opće uvjerenje je da mediji mogu pomoći u obrazovanju djece i razvijanju njihova znanja. No, također mogu proširiti obrazovno i psihološko znanje roditelja te potaknuti roditelje da koriste to znanje u svojim kontaktima s djecom. Na taj način mediji podržavaju obrazovnu funkciju u obitelji. Djeca uče putem modela te ako roditelj koristi medije nekontrolirano, vrlo je vjerojatno da će dijete slijediti taj primjer. Roditelji trebaju voditi djecu svojim primjerom, koristiti informatičku tehnologiju regulirano i objašnjavati djeci pozitivne i negativne aspekte istih. Roditelji koji s djecom gledaju televiziju, koji im objašnjavaju i paze na sadržaj koji djeca gledaju te koji upozoravaju i upućuju na štetne, odnosno pozitivne sadržaje, štite svoju djecu od negativnih utjecaja televizije (Ozdasli, Gol, 2013). Cilj je približiti se djeci, a kako bi se približili djeci i spoznali njihove interese vezane 
uz medije, ključna je komunikacija i zanimanje za dijete te one medijske sadržaje koje ono želi gledati. Važno je da roditelji s djecom pogledaju njihovu omiljenu emisiju ili odigraju omiljenu igricu kako bi spoznali sadržaj te potom kroz razgovor upućivali na pozitivne, odnosno negativne aspekte sadržaja. One obitelji koje su djeci omogućavale pristup informatičkim tehnologijama s prikladnom kontrolom imaju bolje okruženje i atmosferu unutar obitelji. Ozdasli i Gol (2013) smatraju kako je jedna od većih pogrešaka ostaviti djecu pred televizijom ili igricama kako bi upotpunjavali njihovo slobodno vrijeme. Stvar koja se ne bi trebala zaboraviti je da televizija pasivizira djecu i udaljava ih od stvarnih interakcija jer čak i oni programi koji imaju obrazovnu i edukativnu svrhu nakon nekog vremena pretvaraju djecu u pasivne primatelje medijskih sadržaja.

Naposljetku, igra između roditelja i djece ima vrlo važnu ulogu u učenju. Mnogi roditelji bi željeli provoditi puno više vremena sa svojom djecom, no zbog posla i drugih obaveza za igru s djecom im preostaje malo vremena. No, bez obzira na količinu vremena koju provode sa svojom djecom, važno je stvarati atmosferu sigurnosti, topline, ljubavi i povjerenja.

Važnu ulogu u medijskom odgoju imaju i odgojitelji predškolske djece u dječjim vrtićima. Odgojitelji bi trebali biti „medijatori“ odgojno poželjnih utjecaja medija te bi cilj medijskog odgoja u vrtiću trebao biti usmjeren na razvoj medijske kompetentnosti i razvijanju aktivnog i kreativnog odnosa prema medijima (Sindik, Veselinović, 2010). Nadalje, Joško Sindik i Zvjezdana Veselinović (2010) smatraju da pedagoško djelovanje odgojitelja treba biti usmjereno na analizu medijskog sadržaja, na opažanje doživljaja pojedinog medija te upućivati na razliku realnog svijeta i onog predstavljenog u medijima. Nadalje, uloga odgojitelja vezana uz medije treba biti usmjerena na educiranje o prepoznavanju kvalitetnog medijskog sadržaja, o procjeni kvalitetnih videoigara te educirati o možebitnim pozitivnim, odnosno negativnim utjecajima televizije, interneta i računala. Također, odgojitelji bi trebali osvještavati i educirati roditelje o medijima. U dječjem vrtiću postoji više načina na koji se može obavljati ova djelatnost, poput informiranja o medijima putem kutića za roditelje, organiziranjem komunikacijskih i tematskih roditeljskih sastanaka te upućivanjem na stručne izvore koji se osvrću na utjecaj medija i medijski odgoj. No, da bi navedeno bilo moguće, vrlo je važna potpora sustava vezana uz stručna usavršavanja odgojitelja na ovom polju. Odgojitelji kao i roditelji moraju preuzeti odgovornost, jačati svoje kompetencije na području medijske i računalne pismenosti jer je to nužan preduvjet medijskog opismenjavanja djece. 


\section{Zalključak}

S obzirom na to da se svaki dan svijest ljudi prema medijima mijenja i istovremeno jača utjecaj medija, a kako bi djeca razumjela i ovladala današnjim načinom života, medijski sadržaji bi trebali biti implementirani u odgoj i obrazovanje djece od najranije dobi. Lakše dolaženje do informacija, kao i količina informacija kojom dijete raspolaže korištenjem medija, pozitivno utječe na školski, ali i na društveni uspjeh, što olakšava razvoj samosvjesnog i samopouzdanog odraslog čovjeka kao aktivnog člana društvene zajednice. Činjenica je da djeca provode mnogo vremena uz različite medijske sadržaje te koriste interaktivnu tehnologiju u formalnim i neformalnim oblicima učenja što itekako ima utjecaj i na obiteljski život.

Društvo znanja je društvo koje uči, a znanja i kompetencije kontinuirano se razvijaju. Učitelji, odgojitelji i roditelji, kao najvažnije osobe u dječjoj okolini, moraju biti spremni na cjeloživotno učenje. Ono bi, između ostalog, trebalo podrazumijevati usvajanje digitalnih kompetencija kao vrlo važnog odgojnog faktora u globalnom svijetu. Potrebno je naglasiti važnost stvaranja koherentnog sustava koji bi mogao dovesti do oblikovanja ključnih kompetencija u predškolskim ustanovama kako bi se osigurao uspješan početak školovanja i cjeloživotno učenje. Mandarić (2012) smatra da je zadaća odraslih osvijestiti djecu i mlade o odgovornosti, razboritosti, umjerenosti i mudrosti u korištenju medija kako bi im u odrastanju oni bili prijatelji i saveznici. Dakle, ne zabrana medija, nego odgoj za zrelo i odgovorno korištenje medija, i to od najranije dobi.

\section{Popis literature}

- Anetta, L. A. (2008). Video Games in Education: Why They Should Be Used and How They Are Being Used, Theory Into Practice. The College of Education and Human Ecology. The Ohio State University: Routledge.

- Bradea, A., Cosmin Blandul, V. (2015). The impact of Mass medio upon Personality Development of Pupils from primary school. Procedia - Social and Behavioral Sciences, 205, 296-301.

- Baacke, D. (2007). Medienpädagogik. Tübingen: Max Niemeyer.

- Burić, J. (2011). Djeca i mladi kao konzumenti masovnih medija. Etika i tržišne manipulacije potrebama mladih. Filozofska istraživanja, 30 (4), 629-634.

- Chou, M., Fen, C. (2014). Parent-child Play within Information Technology: A Quest for Quality Familiy Atmosphere. Social and Behavioral Science, 122, 273-282.

- Ciboci, L., Kanižaj, I., Labaš, D. (ur.) (2011). Djeca medija. Od marginalizacije do senzacije. Zagreb: Matica hrvatska.

- Forma, P., Matyjas, B. (2015). Digitalization of Upbringing and Education in Relation to Shifted Socialisation of Polish Students. Procedia - Social and Behavioral Sciences, 176, 985-991.

- Hoffman, B. (2014). Computer as a Threat of an Opportunity for development of children. Procedia - Social and Behavioral Sciences, 146, 15-21. 
- Ilišin, V., Marinović Bobinac, A., Radin, F. (2001). Djeca i mediji: uloga medija u svakodnevnom životu djece. Zagreb: Državni zavod za zaštitu obitelji, materinstva i mladeži.

- Ivanović, M. (2014). Development of Media Literacy- An Importaint Aspect of Modern Education. Procedia - Social and Behavioral Sciences, 149, 438-442.

- Kovač, E. (2011). Interaktivne multimedijske slikovnice. Dostupno na: http://eprints.grf.unizg.hr/1540/1/DB283_Kovac_Eva. pdf. Preuzeto 15. studenoga 2017.

- Košir, M., Zgrabljić, N., Ranfl, R. (1999). Život s medijima: priručnik o medijskom odgoju za roditelje, nastavnike i učitelje. Zagreb: Doron.

- Kowalski, R. M. (2008). Cyber bullying: Recognizing and treating victim and aggresor. Psychiatric Times. Dostupno na: https://pro.psychcentral.com/cyber-bullying-recognizing-and-treating-victim-and-aggressor/Preuzeto 20. siječnja 2019.

- Krilić, A. (2010). Djeca i mediji. Dostupno na: http://www.roditeljstvo.com/vijesti/djeca-i-mediji-i-uvod-rijec-autora. Preuzeto 25. studenoga 2017.

- Labaš, D. (2011). Djeca u svijetu interneta: zatočenici virtualnog svijeta, 35-64. U: Ciboci, L., Kanižaj, I., Labaš, D. (ur.), Djeca medija: Od marginalizacije do senzacije. Zagreb: Matica hrvatska.

- Labaš, D., Maleš, D. (2017). Percepcija etičnosti elektroničkih medija kod adolescenata u kontekstu sociodemografskih obilježja i medijske pismnosti. Nova prisutnost: časopis za intelektualna i duhovna pitanja, 15 (2), 211-229.

- Mandarić, V. (2012). Novi mediji i rizično ponašanje djece i mladih. Bogoslovna smotra, 82 (1), 131-149.

- Matyjas, B. (2015). Mass media and children. Globality in everyday life. Procedia - Social and Behavioral Science, 174, $2898-2904$.

- Miliša, Z. (2008). Uloga medija u razvoju interkulturalne komunikacije. Pedagogijska istraživanja, 5 (2), $219-229$.

- Miliša, Z., Zloković, J. (2008). Odgoj i manipuliranje u obitelji i medijima. Zagreb: Markom.

- Nacionalni okvirni kurikulum za predškolski odgoj i obrazovanje (2011). Zagreb: Ministarstvo znanosti,obrazovanja i športa.

- Nadrljanski, M., Nadrljanski, Đ., Bilić, M. (2007). Digitalni mediji u obrazovanju. Digital information and Heritage, 527-537. Dostupno na: https://infoz.ffzg.hr/INFuture/2007/PDF/7-08\%20Nadrljanski\%20\&\%20Nadrljanski\%20\&\%20Bilic,\%20 Digitalni\%20mediji\%20u\%20obrazovanju.pdf. Preuzeto 14. rujna 2019.

- Ozdasli, E., Gol, M. (2013). Media and Behavioral Sciences. Procedia - Social and Behavioral Science, 106, $1815-1820$.

- Peruško-Čulek, Z. (2011). Uvod u medije. Zagreb: Naklada Jasenski i Turk: Hrvatsko sociološko društvo.

- Rogulj, E. (2014). Utjecaj novih medija na dječju igru. Croatian Journal of Education: Hrvatski časopis za odgoj i obrazovanje, $16(1), 267-277$

- Samardžić, A. (2013). Važnost masovnih medija u odgoju i obrazovanju. Dostupno na: http://www.djecamedija.org/?p=2627. Preuzeto 1. prosinca 2017.

- Sindik, J. (2012). Kako roditelji percipiraju utjecaj medija na predškolsku djecu? Medijska istraživanja, 18 (1), 5-33.

- Sindik. J., Veselinović, Z. (2010). Kako odgojiteljice percipiraju utjecaj medija na predškolsku djecu. Medijska istraživanja, $16(2), 107-133$

- Sigman, A. (2010). Daljinski upravljani. Velika Mlaka: Ostvarenje.

- Şişman, B., UluğYurttaş, O. (2015). Anempiricalstudy on media literacy from the view point of media. Procedia - Social and Behavioral Sciences, (174), 798-804.

- Stančić, H., Crnec, D., Matelja, S., Salopek, A., Sanković, D. (2007). Usporedna analiza interaktivnih mrežnih servisa. Medijska istraživanja, 13 (2), 39-58.

- Subrahmanyam, K., Kraut, R. E., Greenfield, P. M., Gross, E. F. (2000). The Impact of Home Computer Use on Children's Activities and Development, The Future of Children. Children and Computer Technology, 10 (2), 123-144.

- Suvajdžić, M. (2016). Novi mediji i učenje-utjecaj novih tehnologija na transformaciju visokog školstva (doktorski rad). Beograd: Univerzitet umjetnosti.

- Tabol, S. (2002). Computer in integrated education. Education and Dialog [Edukacja i Dialog], 7.

- Tolić, M. (2008). Aktualnost medijskih kompetencija u suvremenoj pedagogiji. Acta Iadertina, 5 (1), 1-14.

- Poliklinika za zaštitu djece Grada Zagreba (n.p.). Nasilje preko interneta - cyberbullying. Dostupno na: http://www.poliklinikadjeca.hr/publikacije/nasilje-preko-interneta/. Preuzeto 25. studenoga 2017.

- Pravobranitelj za djecu (2017). Istraživanje EU Kids Online prvi put obuhvatilo i djecu iz Hrvatske. Dostupno na: http:// dijete.hr/istrazivanje-eu-kids-online-prvi-put-obuhvatilo-i-djecu-iz-hrvatske/. Preuzeto 26. siječnja 2019. 


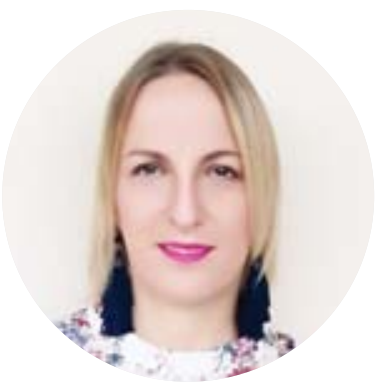

\section{Antonija Đuran Diana Koprivnjak}

Antonija Đuran je rođena 1983. u Zagrebu. Nakon završene XVIII. gimnazije 2001. upisuje Učiteljsku akademiju u Zagrebu, dodiplomski studij predškolskog odgoja te stječe zvanje odgojitelj predškolske djece. Dosadašnji trinaestogodišnji radni staž provela je u dječjem vrtiću Medo Brundo radeći kao odgojitelj u obogaćenom programu - rano učenje engleskog jezika. Diplomski sveučilišni studij ranog $\mathrm{i}$ predškolskog odgoja i obrazovanja na Učiteljskom fakultetu u Zagrebu završila je 2017. godine.

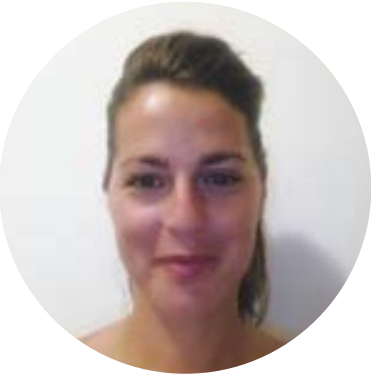

Diana Koprivnjak je rođena 1981. u Zagrebu. Nakon završene III. Gimnazije, 1999. godine upisuje Učiteljsku akademiju u Zagrebu, dodiplomski studij predškolskog odgoja te stječe zvanje odgojitelja predškolske djece. 2012. godine upisuje diplomski sveučilišni studij ranog i predškolskog odgoja i obrazovanja na Učiteljskom fakultetu u Zagrebu te stječe akademski naziv magistra ranog $\mathrm{i}$ predškolskog odgoja i obrazovanja. Od 2007. godine je zaposlena $u$ dječjem vrtiću Medo Brundo.

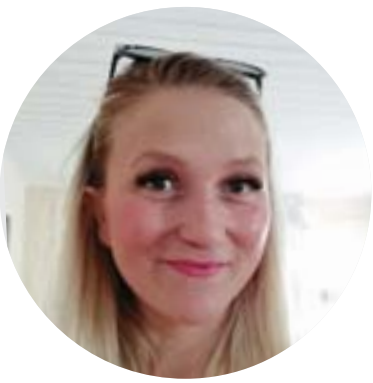

Nataša Maček

Nataša Maček je rođena 1989. u Zagrebu. Nakon završene Škole za medicinske sestre upisuje Učiteljski fakultet, smjer Predškolski odgoj, te stječe zvanje magistar ranog $\mathrm{i}$ predškolskog odgoja i obrazovanja. Iskustva i znanja, osim u vrtiću, stječe i radom u osnovnoj školi te volontiranjem u CIP „IDEM“, Plavom telefonu i Društvu tjelesnih invalida. Sudjelovala je na nekoliko međunarodnih znanstvenih konferencija te je objavila nekoliko znanstvenih i stručnih radova. 